\title{
Black and Blue: Exploring Racial Bias and Law Enforcement in the Killings of Unarmed Black Male Civilians
}

\author{
Alison V. Hall \\ Department of Management \\ University of Texas, Arlington \\ 701 S. West Street, Suite 224 \\ Arlington, TX 76010 \\ E-mail: avhall@uta.edu \\ Erika V. Hall \\ Goizueta Business School \\ Emory University \\ 1300 Clifton Road \\ Atlanta, GA 30322 \\ E-mail: erika.hall@emory.edu \\ Jamie L. Perry \\ School of Hotel Administration \\ Cornell University \\ 565D Statler Hall \\ Ithaca, NY 14853 \\ E-mail: jlp358@cornell.edu
}

Published in American Psychologist (2016), Vol. 71, No. 3, 175-186 


\begin{abstract}
In late 2014, a series of highly publicized police killings of unarmed Black male civilians in the United States prompted large-scale social turmoil. In the current review, we dissect the psychological antecedents of these killings and explain how the nature of police work may attract officers with distinct characteristics that may make them especially well-primed for negative interactions with Black male civilians. We use media reports to contextualize the precipitating events of the social unrest as we ground our explanations in theory and empirical research from social psychology and industrial and organizational (I/O) psychology. To isolate some of the key mechanisms at play, we disentangle racial bias (e.g., stereotyping processes) from common characteristics of law enforcement agents (e.g., social dominance orientation), while also addressing the interaction between racial bias and policing. By separating the moving parts of the phenomenon, we provide a more fine-grained analysis of the factors that may have contributed to the killings. In doing so, we endeavor to more effectively identify and develop solutions to eradicate excessive use of force during interactions between "Black” (unarmed Black male civilians) and "Blue” (law enforcement).
\end{abstract}

Keywords: race, law enforcement, prejudice, bias, stereotyping 


\section{Black and Blue: Exploring Racial Bias and Law Enforcement in the Killings of Unarmed Black Male Civilians}

In late 2014, a maelstrom erupted over several police killings of unarmed Black male civilians. The events that ensued caused U.S. citizens to question their institutions and allegiances. Race was a strong undercurrent in the discourse, as there was contention over the influence of racial bias against Blacks in the shootings. Further, a chasm developed between law enforcement and civilians, as many citizens questioned whether they were protected or persecuted by these institutional authorities (see New York Times Poll, 2014). Notably, some observers perceived the identities and intentions of police and racists to be synonymous (Hudson, 2014; Sperry, 2014). However, we argue that the automatic conflation of these two identities is problematic for three primary reasons.

First, by conflating law enforcement's and racists’ motivations, concerned observers fail to disentangle the unique social-psychological antecedents of the killings. Second, a hyper focus on police officers' racial bias diminishes the impact of the larger epidemic of racism within the greater population. If racial biases are broadly held among the public, but the discussion is limited solely to police-civilian encounters, the racial bias present in our broader society will be overlooked. Third, the formation of an entitative “outgroup” (e.g., racist police officers) creates and/or reinforces adversarial tensions between police officers and communities that may stall collaborative reform efforts. Accordingly, in this article, we attempt to facilitate discourse that acknowledges and assesses racial bias, but also extends that conversation to other factors that may be more amenable to productive partnerships and effective solutions. 
In this review, we explore the psychological undercurrents of the events related to law enforcement agents killing unarmed Black male civilians (see Figure 1 for the most highly publicized fatal encounters between law enforcement agents and unarmed Black male civilians). We do not purport to know the police officers in question or attempt to reconstruct any single event. Instead, our primary contribution is to situate these sociohistorical events in the context of psychological theory and empirical research to explain some of the normative influences that may have impacted these incidents and that likely contribute to the ongoing contention between “Black” (unarmed Black male civilians) and “Blue” (law enforcement). First, we deconstruct encounters between police and Black male civilians by isolating generalized racial bias (e.g., negative stereotyping) from specific attributes of law enforcement (e.g., nature of the work and prevalent traits). We then clarify how these mechanisms may interact to result in especially excessive use of force during police-civilian encounters with Black male civilians. Finally, we make recommendations for law enforcement, society, and police-civilian partnerships.

\section{Black: The Nature of Racial Bias}

According to a ProPublica analysis of federal data on fatal police shootings between 2010 and 2012, young Black male civilians were 21 times more likely to be killed by police than young White male civilians (Gabrielson, Jones, \& Sagara, 2014). As such, race has been a powerful and polarizing theme in the discourse around the fatal encounters between police and Black male civilians. However, research on implicit versus explicit bias suggests that - above and beyond police officers - the general public may also favor Whites over Blacks, but may not be cognizant of their prejudices. Implicit bias occurs when a discriminator is not consciously aware of his or her own bias, whereas explicit bias occurs when a discriminator is able to 
introspectively self-report these biased behaviors or attitudes (Greenwald \& Banaji, 1995). In the current research, we review studies of implicit and explicit bias that illustrate three stereotypes that may be especially harmful for Black male adults and children within the context of this conflict. We argue that the implicit nature of these stereotypes impedes our ability to recognize their prevalence at the societal-level among both White and Black Americans.

\section{Black Youth as Adult-Like}

Racial bias starts early as Black youth face detrimental stereotypes with which other youth do not have to contend. In a series of studies, Goff, Jackson, Di Leone, Culotta, and DiTomaso (2014) instructed both undergraduate student and police officer participants to evaluate young Black, White, or Latino suspects and estimate their age and culpability for their actions. Black boys were perceived to be older and less innocent than White boys, and this “adult-like” quality made them appear to be more appropriate candidates for greater use of police force. While the participants’ estimations were explicitly endorsed, the explicit ratings were undergirded by an implicit dehumanization of Blacks as vicious, violent animals. Both civilian and police officer participants perceived Black youth to be older than they were (an average of 4.53 and 4.59 years older, respectively; Goff et al., 2014). This suggests that force typically used on adults may be perceived as appropriate for a 14-year-old Black teenager.

This research harkens back to the shooting of Tamir Rice, a 12-year-old Black boy initially estimated to be around 20-years-old by the police officer who killed him (Lopez, 2014; Phillip, 2014). While we cannot causally infer that Tamir's older perceived age factored into his shooting death, the fact that police officers perceived him to be 8 years his senior may have 
factored into the intentions Tamir was presumed to have, the pain they believed he could withstand, and/or assessments of the apt level of force (see Trawalter, Hoffman, \& Waytz, 2012).

\section{Blacks as Sub- and Superhuman}

The statement “Black Lives Matter” became a trending social media hashtag and a persistent theme during the 2014 and 2015 civil demonstrations (Eligon, 2015). The use of this slogan suggests that some people believe Blacks may be viewed as subhuman within American society, such that their lives are devalued relative to the lives of Whites. Research supports the notion that Blacks have been dehumanized in American culture. For example, Goff, Eberhardt, Williams, and Jackson (2008) found that Blacks are implicitly associated with apes. In their study, participants were subliminally primed with White and/or Black faces and asked to identify line drawings of apes versus nonapes. Participants who were primed with Black male faces more easily identified the ape drawings, suggesting that Black male faces make the concept of an ape more accessible on a nonconscious level.

Importantly, these associations have consequences for the degree to which people see Blacks as human, and consequently, evaluations of the extent to which their lives matter. In a subsequent study of implicit bias, Goff et al. (2008) subliminally exposed White male participants to ape-related words and asked them to watch a tape of a Black or White suspect being beaten by police officers. Participants who were subliminally exposed to ape-related words were more likely to believe that the police officers' acts of violence were justified when they watched a tape of a Black, but not White, suspect being beaten.

Furthermore, research suggests that Blacks are also perceived to be superhuman—or “possessing mental and physical qualities that are supernatural . . . extra sensory . . . and 
magical” (Waytz, Hoffman, \& Trawalter, 2015, p. 1). Waytz et al. (2015) found that Whites’ perceptions of Blacks as superhuman were associated with their beliefs that Blacks had higher pain thresholds. This suggests that a Black target is perceived as less susceptible to harm, and more invincible to physical blows than a non-Black person (see also Tait \& Chibnall, 2014).

Police officers may similarly endorse stereotypic associations that dehumanize Blacks and this may have material consequences for the Black male civilians under their purview. For example, Goff et al. (2014) linked police officers’ implicit dehumanization of Black boys to their past use of force against Black youth (relative to White youth) as noted in officers’ personnel records. If officers perceive Black male civilians as superhuman, they may also more easily justify extreme physical acts against Black male targets in alignment with a "superhero" versus “villain” narrative. In Officer Darren Wilson’s 2014 grand jury testimony, he remarked that he “felt like a five-year-old holding onto Hulk Hogan” (Calamur, 2014), emphasizing the superhuman qualities he believed that Michael Brown possessed.

\section{Blacks as Violent and Criminal Threats}

Finally, the well-known "Blacks as criminals" stereotype is also pervasive at an implicit level. Eberhardt, Goff, Purdie, and Davies (2004) found that participants more quickly identified disguised photos of crime-related objects (e.g., guns) after being subliminally primed with Black (vs. White) faces. To gauge explicit prejudicial beliefs toward Blacks, participants indicated the extent to which they agreed with prejudicial statements (e.g., "Over the past years, Blacks have gotten more economically than they deserve”; Modem Racism Scale, McConahay, 1986).

Notably, the speed at which these crime-related objects were identified was unrelated to participants’ explicit prejudicial beliefs. 
Although people may believe they are unbiased against Blacks, subconscious associations between Blacks and crime-related concepts may even affect the light in which an altercation is perceived. For instance, in a classic behavioral study, Duncan (1976) exposed participants to a scene in which one student shoved another. Participants perceived the person shoving as more violent when he was depicted as a Black, rather than White, student. Similarly, the Black- criminal association may have contributed to Trayvon Martin and Jordan Davis being branded as “thugs” (criminal offenders) despite their statuses as victims in their altercations with George Zimmerman and Michael Dunn, respectively (Bouie, 2014; Cadet, 2013).

\section{Stereotypes in the Context of Shooter Bias}

Stereotypes about Black men also influence “shooter bias” (Cornell et al., 2007; Cornell, Park, Judd, \& Wittenbrink, 2002; Sim, Correll, \& Sadler, 2013). In shooter bias experiments, participants are instructed to make quick decisions about whether to shoot or not shoot Black or White targets in a computer simulation. The targets either hold guns or nongun objects (e.g., cell phone, wallet) in each trial, and participants are tasked with quickly evaluating the threat posed by each suspect before deciding to shoot.

Correll et al. (2002) demonstrated that participants more frequently shot unarmed Black, rather than White, male targets. Consistent with the case of Lavar Jones, a Black man who was shot as he wielded his wallet (Crockett, 2014), the study showed that the criterion for threat was lower for Black, than for White, male suspects (Correll et al., 2002). Further, participants fell prey to shooter bias; they chose to shoot armed Black (vs. White) men more quickly and chose not to shoot unarmed White (vs. Black) men more quickly. As measured by the Modem Racism prejudices against Blacks were again unrelated to their shooter biases. However, their knowledge 
of the cultural stereotype of Blacks as violent did influence their bias against Black targets. Participants that were aware of these cultural stereotypes, even if they did not personally endorse them, were quicker to shoot a Black (vs. White) armed man, and quicker to dismiss a White (vs. Black) unarmed man as a nonthreat.

Research suggests that the effect is stronger for Black men than for any other race by gender target group. Plant, Goplen, and Kunstman (2011) asked participants to perform the Shooter Bias task using Black and White, female and male targets as suspects. Participants were significantly more likely to erroneously shoot unarmed Black men than unarmed Black women, White men, and White women. Further, participants were significantly more likely to mistakenly choose not to shoot armed Black women, White women, and White men, than Black men.

Notably, some shooter bias studies have employed Black civilian and Black police officer participants to examine if shooter bias is specific to non-Blacks. The studies found that Blacks’ racial bias in the Shooter Bias task is equivalent to that of non-Blacks (Correll et al., 2002; Plant, Peruche, \& Butz, 2005). This underscores that shooter bias is perpetuated by knowledge of cultural stereotypes, rather than an explicit propensity to discriminate against Blacks.

All of this evidence supports the position that stereotypes associated with "Blackness" are pervasive; yet, they are generally independent of explicit prejudicial beliefs. Thus, a person may act on these stereotypes without conscious awareness or malicious intent. Further, these stereotypes are held by the general population, and they are not specific to law enforcement agents or Whites alone. Thus, interventions proposed to combat racial prejudice in police departments may be well supported by larger socialization efforts in our society (e.g., media portrayals that display Black integrity, humanity, and innocence). Nonetheless, in the next 
section, we more closely examine the psychosocial properties that are specific to police officers and their job demands.

\section{Blue: The Nature of Law Enforcement}

In an ABC News interview, Officer Darren Wilson, who was responsible for the fatal shooting of unarmed teenager Michael Brown, explained his thoughts on the encounter. He stated, “The reason I have a clean conscience is that I know I did my job right” (ABC News, 2014). A common sentiment expressed in the aftermath of police shootings is that the officers are “just doing their jobs” (Swaine, 2014). Thus, in this section, we discuss how police culture and the nature of police work exacerbate modes of thinking that may contrast officer interests from civilian interests. Further, since people make their career choices based on their own interests and personalities (Holland, 1985), we argue that a certain type of individual is attracted to policing and consider characteristics that distinguish officers from the civilian population.

Trait activation theory suggests that people pursue work that offers ample opportunities to express their inherent traits and preferences (Tett \& Burnett, 2003; Tett \& Guter- man, 2000; Tett, Simonet, Walser, \& Brown, 2013). We argue that the attributes of police work and culture appeal to individuals who (a) desire intergroup connectivity; (b) hold values that promote order; and (c) appreciate social hierarchy, to a greater extent than the average American civilian. Moreover, we posit that the job affords officers opportunities to express these traits as they meet the job demands and reinforces their similarity to one another and their distinctiveness from civilians in general (and Black male civilians, specifically).

\section{Distinct Collective Identity Orientation}


Law enforcement may be attractive to individuals who seek professions with strong collective identities. After the widespread public outrage that followed the highly publicized killing of Michael Brown, many officers wore paraphernalia proclaiming “I am Darren Wilson,” in demonstrations of unanimity that would likely be atypical for the generic American workplace (Johnson, 2014). However, officers are bonded in a uniquely strong and salient collective—a "brotherhood" — that supersedes many of their individual dissimilarities and disparities (Crank, 2014). Furthermore, approximately 88\% of American police are men (United States Department of Justice, 2007), and theory suggests that men may be more group oriented than women (Baumeister \& Sommer, 1997).

A strong group orientation can, however, lead to heightened "us vs. them” worldviews (Tajfel \& Turner, 1979) that may become particularly strong for men in threatening situations (Van Vugt, De Cremer, \& Janssen, 2007). Of course, threat is constantly salient in police work and training (Jamieson, Suren, \& Knapp, 2000). For example, officers commonly use outsider labels like "suspect” and "perpetrator” that may prime them to perceive civilians as realistic threats to their physical well-being (Stephan \& Stephan, 1996, 2000). An analysis of secondary data from a sample of 1,104 Baltimore City police officers revealed that $72.8 \%$ of the officers reported having "frequent contact with suspects” and 78.3\% reported having "experienced physical contact with suspects” (Dowler, 2005). Officers may cope with these perceived threats by becoming highly suspicious and somewhat preoccupied with maintaining the edge during police-civilian exchanges (Paoline, 2003; Rubenstein, 1973; Skolnick, 1994). They may also hold some degree of animosity and develop "us vs. them” attitudes toward civilians (Paoline, 2003). As such, officers may also develop more homogenous negative attitudes and beliefs about outsiders that negatively influence their perceptions of, and interactions with, the communities to 
which they are dispatched (Loftus, 2010). Thus, as the ever-present threat of danger reinforces officers’ vow to "Blue,” it distances them from "non-Blue.”

Insert Figure 1 Here

\section{Distinct Values}

Police work may also attract people with unique values. Police culture promotes positive values such as solidarity, loyalty, duty, and honor (Crank, 2014). However, Bardi, Buchanan, Goodwin, Slabu, and Robinson (2014) compared a sample of police trainees to a control group of civilians and revealed that, relative to the general population, police trainees in their second week in the academy also appraised "conformity" and "power” as significantly more important values. This suggests that we could expect the average police trainee to value "restraint of actions, inclinations, and impulses likely to upset or harm others and violate social expectations or norms” and ". . c control or dominance over other people and resources,” as those are the definitions of conformity and power, respectively (Schwartz, 1994, p. 22). Trainees also rated “universalism” and “self-direction” as significantly less important values than the general population. Thus, we could expect the average officer to place less value on "understanding, appreciation, tolerance, and protection for the welfare of all people” and "independent thought and action-choosing, creating, [and] exploring," as these are the very definitions of universalism and self-direction values, respectively (Schwartz, 1994, p. 22). Nine months later, after being socialized into the job, the trainee officers' distinct values remained intact (Bardi et al., 2014).

Critically, the values common among individuals attracted to the field of policing may not prepare them for the most positive interaction with civilians. For example, research shows 
that readiness for outgroup contact is negatively associated with conformity values, but positively associated with universalism and self-direction values (Sagiv \& Schwartz, 1995). Notably, perceived differences between officers and civilians may also cause officers to perceive civilians as symbolic threats to their own values and missions (Stephan \& Stephan, 1996, 2000) and further intensify the "us vs. them” divide.

Further, values may also influence how officers perceive and respond to minor offenses. For example, Feather (1996) asked study participants to review a scenario in which an individual refused to obey a police order. For his or her noncompliance, the individual was fined and arrested. Participants with high conformity and low universalism values (similar to those commonly held by police officers) evaluated the failure to comply as more serious, believed the offender was more deserving of the penalty, rated the penalty as less harsh, and had less sympathy for the offender. Since noncompliance is counter to the conformity values that police officers hold in high esteem, it is unsurprising that in many cases of police violence against unarmed civilians (e.g., Eric Gamer), officers cite “failure to comply” or "resisting arrest” as a precursor and justification to the decision to use lethal force (see Patton \& Leonard, 2014). Ironically, research shows that civilians are more apt to empower officers and to cooperate and comply with their demands when there is perceived value congruence (Sunshine \& Tyler, 2003).

\section{Distinct Ideology}

Police work may also draw individuals who subscribe to unique social order beliefs. The police occupation adheres to a hierarchical rank and file organizational structure and top-down management style (e.g., Bayley, 2008; Gau \& Gaines, 2012; Sklansky \& Marks, 2008). This type of environment may be especially attractive to individuals with a high social dominance 
orientation (SDO). SDO is defined as the extent to which individuals value the maintenance of hierarchical group superiority in their interactions with others (Pratto, Sidanius, Stallworth, \& Malle, 1994). Research demonstrates that college students with high SDO are more attracted to hierarchy-enhancing careers (e.g., police, judges, etc.) that are primarily aimed at protecting, serving, or benefiting society’s elite (Pratto et al., 1994; Sidanius, Pratto, Sinclair, \& Van Laar, 1996; Sidanius, Van Laar, Levin, \& Sinclair, 2003).

As such, it is unsurprising that research also suggests that police officers hold SDO ideologies to a greater extent than does the general population. Using data from an anonymous opinion survey, Gatto, Dambrun, Kerbrat, and De Oliveira (2010) found that, compared to the control group from the general population, both newly recruited and more seasoned officers held significantly stronger levels of SDO. Junior officers’ perceptions of SDO among their peers also

further reinforce their own ideologies (Gatto \& Dambrun, 2012). Consistent with research related to ideology and person-organization congruence (see Haley \& Sidanius, 2005), this research suggests both selection and socialization effects (Gatto \& Dambrun, 2012). Thus, individuals with high SDO may pursue jobs in law enforcement and their beliefs may be strengthened as their tenure lengthens. Since police work is characterized by significant power distance between internal ranks and also authorizes officers to exercise power over civilians (Paoline, 2003), it may be well-suited for the expression of SDO. However, individuals who are high in SDO also tend to favor more severe punishment when members of subordinate groups fail to submit (Pratto et al., 1994). As such, police officers with high SDO are likely to inflict more severe punishment on civilians who do not adhere to their demands during police-civilian interactions.

\section{Distinct Experiences With Black Male Civilians}


Finally, research suggests that officers’ encounters with Black male civilians may be particularly precarious. Meta-analytic evidence reveals that negative stereotypes (like those associated with Black men and boys) predict both realistic and symbolic intergroup threat, as well as intergroup anxiety (Riek, Mania, \& Gaertner, 2006). Realistic threat (i.e., perceived danger) and symbolic threat (i.e., perceived value incongruence) also have stronger impacts on negative outgroup attitudes (e.g., suspicion) when the threatening outgroup is lower status (e.g., Black) rather than higher status (e.g., White; Riek et al., 2006). Ironically, recent research suggests that since Black men expect to be negatively stereotyped by police, they also anticipate greater anxiety and self-regulatory efforts during police encounters, and, consequently, may be more likely to engage in behavior that is perceived as suspicious by police officers (e.g., avoiding eye contact; Najdowski, Bottoms, \& Goff, 2015).

Additionally, Navarrete, McDonald, Molina, and Sidanius (2010) suggest that crossracial intergroup interactions between males may be more physically aggressive than those between females or mixed-sex dyads. In a series of lab studies, they demonstrated that when SDO motives are high, men are even more likely to engage in physically aggressive behaviors against outgroup males. This evidence, taken together with the research that finds that White American officers have especially high SDO (e.g., Sidanius, Liu, Pratto, \& Shaw, 1994) and the 88\% male and 75\% White national police demographics (United States Department of Justice, 2007), suggests that we are likely to see the average American officer engage more aggressively with male, rather than female, civilians and Black, rather than White, civilians. Thus, Black male civilians and White male officers are poised to experience more physically aggressive conflict.

\section{Solutions}


With the Department of Justice's indictment of the Ferguson Police Department for racially biased policing (United States Department of Justice, 2015), as well as their probe into the death of Freddie Gray in Baltimore (Verhovek, 2015), there is increased public impetus for police reform. We agree that institutional reform is critical. However, since racial bias neither begins nor ends with police, calls for change must extend beyond police organizations. Thus, we apply principles of both social and industrial and organizational (I/O) psychology to offer suggestions for society and joint police-community partnering. Then, we offer recommendations for law enforcement to better enable those partnerships and support systemic reform.

\section{Recommendations for Society}

\section{Address Racial Prejudice at a Younger Age}

Because officers’ racial biases may be due to their exposure to normative influences within society, we should address racial bias within the larger population. Research suggests that, relative to adults, children are more amenable to racial bias reduction strategies. Kang and Inzlicht (2012) showed that children under age 10 were more receptive to instruction about biases and stereotypes, while older children were more influenced by their personal experiences (see also Kang \& Apfelbaum, 2012). Thus, integrating racial bias reduction efforts into elementary school education may be more constructive than waiting until adults make career choices and enter the workforce.

\section{Increase Cross-Racial Engagement}

We also suggest that interracial engagement and interaction help alleviate some intergroup bias (Allport, 1954; Antonio et al., 2004). Cross-racial communication could provide 
more depth of thought, allowing people to question broad-brush assumptions of entire demographic groups (e.g., Black men are criminals). For example, when Whites are exposed to Blacks’ opinions in small group discussions, they develop more complex, novel contributions to the debate (Antonio et al., 2004). As such, engaging Whites in discussions of racial issues may help them think more introspectively about interracial relations and police brutality. Cross-racial contact may also support more positive intergroup relations in general. For example, White college students with cross-race roommates tend to have more diverse friendship bases, experience less interracial anxiety, and are more likely to value diversity after only a few months (Gaither \& Sommers, 2013). Then, as widely held stereotypical beliefs related to Black male civilians shift, calls for systemic reform may be more pronounced and better supported.

\section{Recommendation for Joint Police and Community Efforts}

\section{Support Community Policing}

Contact theory suggests that contact experiences between equal status groups that share common goals facilitate more positive interactions (Allport, 1954). As such, we recommend frequent, high-quality, positive interaction between officers and civilians centered on the mutual goal of ensuring public safety. We assert that community policing, a systematic approach to policing with the goal of instilling a sense of community to improve the quality of life (Oliver, 2001), may be a useful tool that supports healthier contact experiences between officers and civilians and aligns their interests. Since community policing is a strategic partnership between police and civilians that requires officers to become more embedded in the communities within which they work, it may help to bridge the divide between officers and civilians (i.e., counteract the "us vs. them” dynamics). Community policing entails greater reciprocity between officers 
and civilians as they are mutually involved in coproducing public safety (Greene, 2000; Skolnick \& Bayley, 1986). Notably, research shows community policing may be very useful in areas like Ferguson, Baltimore, and Chicago where police-civilian relations lack mutual trust and where police legitimacy is low (e.g., Hawdon, 2008). It helps reduce tensions between police and minorities (Thomas \& Bums, 2005), and it can effectively reduce serious crime (e.g., Connell, Miggans, \& McGloin, 2008). Black citizens are also very willing to participate in policecommunity partnerships (Wehrman \& De Angelis, 2011).

However, most police departments make minimal efforts to promote community policing (Chermak \& Weiss, 2006). This may be because community policing is difficult to implement effectively under the cues inherent in the traditional U.S. police culture (Taylor, Fritsch, \& Caeti, 1998; Vito, Walsh, \& Kunselman, 2005). After all, “broken windows policing,” a form of high contact policing where officers hone in on petty crimes in order to prevent more dangerous crimes, was in action during the events that preceded Eric Gamer’s death. This underscores the importance of the nature (not just the frequency) of the contact between officers and civilians. Relative to traditional policing activities, community policing focuses on more relational values during officer-civilian interactions (Miller, 1998). Thus, a shift in the nature of the work must coincide with the attraction and retention of a different type of officer and supported by a different type of occupational culture. Accordingly, we now turn to specific recommendations that will support law enforcement's transition toward more effective joint police-community interventions and reduced racial bias.

\section{Recommendations for Law Enforcement}

\section{Diversify Police Forces}


Because both surface and deep-level diversity have important workplace outcomes (Harrison, Price, \& Bell, 1998), we recommend that police departments diversify in both values and demographics. Departments with more egalitarian climates as well as more gender and racial/ethnic diversity tend to more successfully execute community policing efforts (Schuck, 2014). Egalitarian climates, however, are at odds with the high power values and SDO that are currently prevalent among officers. Supporting the case for gender diversity, the average male (relative to female) officer is more than twice as likely to have a citizen name him in a complaint of excessive force and over 8.5 times more likely to have an allegation of excessive force sustained against him (The National Center for Women \& Policing, 2002). Further, since interactions with cross-raced males tend to be more physically aggressive (Navarrete et al., 2010), racial imbalances between communities and their police forces may be especially problematic. Thus, the predominantly White and male demographics, along with the persistent ideologies of the existing force, may hinder community policing efforts. Importantly, because greater diversity within law enforcement organizations necessarily inhibits perceptions of prototypicality, less homogeneity should also promote more positive intergroup attitudes and weaken “us vs. them” distinctions (Waldzus, Mummendey, Wenzel, \& Weber, 2003).

\section{Rotational Assignments to Address Shooter Bias}

Since officers receive extensive weapons training, their shooter bias is less pronounced than that of civilians (Correll et al., 2007). Their training, however, may be undermined by their job assignments. Sim et al. (2013) investigated the benefits of training by having participants complete a counterstereotypic, as compared to prostereotypic, shoot/no-shoot task. Training only reduced shooter bias in the counterstereotypic task in which the number of White (as compared 
to Black) weapon-wielding video game avatars was oversampled. Consequently, the benefits of training may be limited.

In reality, officers who are most likely to make shoot/no- shoot decisions are those who are assigned to "street crime units" that focus intently on gangs in minority communities as opposed to servicing civilians who need their aid. Since training is only beneficial to the extent that it helps shooters disassociate the "Blacks as criminals" cultural stereotype from a "correct" performance on the shoot/no-shoot task, increased interaction with Blacks who fit stereotypical criminal depictions may derail the beneficial effects of weapons training (Plant et al., 2005). In other words, repeated experience that indicates that race is a diagnostic cue for determining a threat (e.g., constant interaction with gangs in all-Black communities) will increase shooter bias; whereas, experience that indicates that race is nondiagnostic of threat (e.g., helping elderly minority citizens cross the street) may mitigate shooter bias. We suggest that rotational assignments that require interaction with a wider range of minority civilians may undermine the cultural stereotype linking Blacks to criminality and further reduce shooter bias for anyone who falls prey to that stereotype (including Black police officers).

\section{Require Diversity Training}

We also suggest continual, mandatory diversity training for all law enforcement in order to combat explicit and implicit racial biases (Cox \& Blake, 1991). In a metaanalysis, Bezrukova, Spell, Perry, and Jehn (2014) demonstrated that diversity training has an immediate, positive, and stable impact on cognitive learning outcomes (i.e., declarative knowledge about cultural diversity issues). Diversity training had greater positive effects when it was complemented with 
additional diversity initiatives that were targeted to both awareness (e.g., self-awareness of stereotyping) and skill development (e.g., practice resolving conflict).

Similarly, Devine, Forscher, Austin, and Cox (2012) found that awareness of implicit bias, concern about its effects, and the application of bias-reduction strategies lead to its ultimate reduction. Thus, we suggest employing diversity training programs that focus on self-awareness and skill-building strategies to help reduce biases. Examples of skill-building strategies include: counterstereotypical imaging (e.g., imagining counterstereotypic others; Blair, Ma, \& Lenton, 2001), increased intergroup contact (Binder et al., 2009; Page-Gould, Mendes, \& Major, 2010), individuation (e.g., obtaining specific information about group members; Bregman, 2012), perspective-taking and giving (e.g., Bruneau \& Saxe, 2012), and stereotype replacement (Monteith, 1993). Since evidence suggests that it is more effective to conduct training over a significant period of time (Bezrukova at al., 2014) and that consistent on-the-job training increases training transfer (Goldstein \& Ford, 2003), we suggest that recurrent upskilling on cultural awareness and skill-building workshops may counteract racial bias against minorities.

\section{Require Leadership Buy-In}

Some prevalent ideologies among police officers may be amenable to less bias under the right leadership. For instance, Umphress, Simmons, Boswell, and Triana (2008) demonstrated that although individuals with high SDO were less likely to select female or minority candidates, the negative effects of high SDO were tempered when superiors instructed selectors to use legitimate criteria in their evaluations. This suggests that the rank-and-file nature of police culture may be advantageous for change if leadership is sincerely committed to diversifying the occupation and shifting its values and practices. This underscores the importance of top 
management support for diversity efforts (Cox \& Blake, 1991), and it offers hope that departments may already have some of the tools they need to effect positive change.

\section{Increase Accountability}

Finally, to address racial bias in policing and equalize status differences between officers and civilians, we suggest mandatory use of body cameras during officer-civilian encounters accompanied by the mandatory use of dashboard cameras during traffic stops. Officers are often not held accountable for their on-duty misconduct (Williams, 2015). However, cameras provide accountability for both officers and civilians as they coproduce public safety. When the job includes a means of oversight, it may support officer performance in meaningfully positive ways (Kerr \& Jermier, 1978; Podsakoff, MacKenzie, \& Bonner, 1996). Accountability may also support training transfer since supervisors can hold trainees accountable for displaying the behaviors (e.g., positive reinforcement) learned in training (Jackson, Schuler, \& Werner, 2011). Recorded evidence of police- civilian interactions may increase officers’ accountability for nonbiased civilian engagement and protect them from being falsely accused of racial bias where none exists. It also equalizes status differences such that an officer's account of an incident is not weighed more heavily than a civilian's account.

\section{Conclusion}

In this review, we have outlined some social psychological mechanisms underlying racial bias as well as a few distinct features of police work and the individuals attracted to that work. We consider the intermingling of racial bias and policing in perpetuating excessive use of force during encounters between police officers and unarmed Black male civilians. In exploring the 
unique effects of racial bias, we reviewed research suggesting that people hold subconscious beliefs that Black youth are perceived as adult-like, and Black male adults are subhuman, superhuman, criminal, and violent. Negative racial biases influence how Black male civilians are treated. Our review summarizes that, as compared to White males, Black males are more likely to be targeted, perceived as suspects, and evaluated as less innocent and more threatening. Next, we propose that police work attracts individuals with distinctive traits (i.e., high collective identity orientation, conformity and power values, SDO). We also explain how value similarities among officers along with the perceived threats inherent in the work may create an impactful schism between officers and civilians. Finally, we highlight how these distinctions may set the stage for especially precarious encounters between officers and Black male civilians.

\section{Limitations and Future Research}

The issues addressed in this review are immensely complex. We acknowledge the boundaries of our focal discussion and highlight a few important limitations of our work. First, we only briefly address bias against Black women or girls. This is for two critical reasons. First, bias against Black men and women may be fueled by distinct mechanisms and is enacted in distinct manners (Navarrete et al., 2010; Plant et al., 2011). Therefore, bias against Black women was beyond the scope of this review. Second, and more critically, social psychological research related to perceived bias and/or the threat of police violence against Black women is scant (see Najdowski et al., 2015; Plant et al., 2011 for exceptions). Thus, there was insufficient research to support a comprehensive discussion. To this end, we implore social psychologists to explore intersectional approaches to the discussion. 
Our review also does not consider biases enacted by the court system. Given that racial bias research suggests that Black male civilians are implicitly viewed as subhuman, superhuman, criminal, and violent (Correll et al., 2002, 2007; Duncan, 1976; Eberhardt et al., 2004; Sim et al., 2013), there may be negative assumptions about their culpability in officer- involved offenses. However, by siding with law enforcement in these cases, court systems may validate racial biases against Blacks and promote (or at least fail to deter) more heavy-handed policing in areas with more Black male civilians. Practitioners may consider developing clear and consistent policies that balance the enforcement and enactment of justice in officer-involved offenses.

Incidents of police violence against unarmed Black male civilians involve multifaceted social issues. Nonetheless, we reiterate a few powerful tools for decreasing the divide between the agents of law enforcement and Black male targets. Though historically police and Black American civilians have not been especially collaborative (Turner, Giacopassi, \& Vandiver, 2006), law enforcement agencies should become more intentional in partnering with the citizens in the communities they are responsible for serving. This offers greater opportunities for positive two-way communication, interaction, and accountability.

As community policing becomes more normalized in the United States, more women and racial minorities may see greater opportunities to thrive in the police occupation. Diversified police forces may be easier to build and sustain as the job demands and occupational values shift. Working more closely with people from diverse backgrounds may also transfer to seeing Black male civilians as more human and deserving of greater respect and consideration. Finally, since the recommendations of this review are informed by research from social and I/O psychology, greater partnerships between researchers and law enforcement agencies may offer valuable insight as well as practical tools that help to assuage ongoing conflict between Black and Blue. 


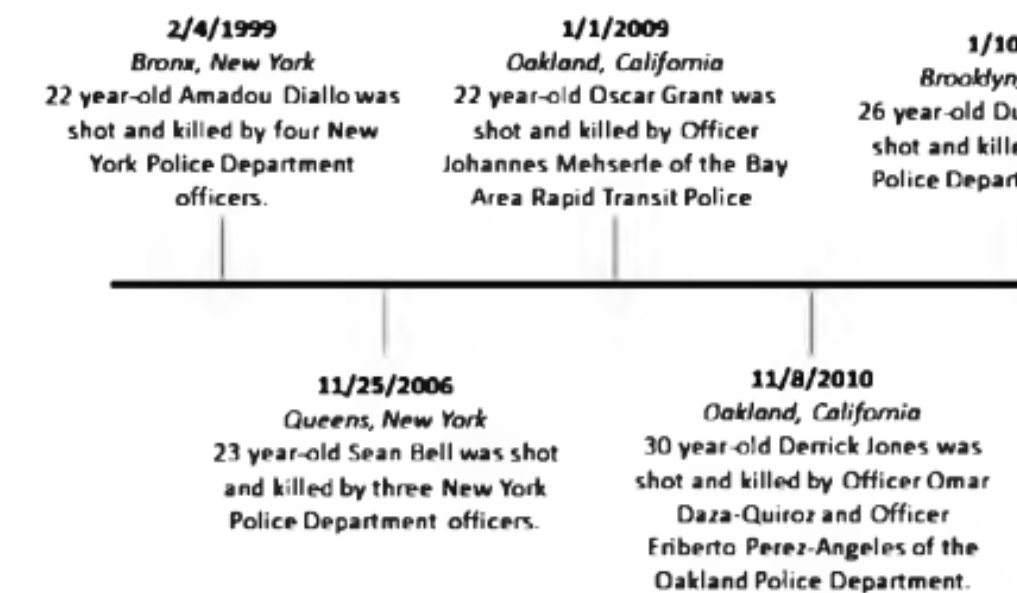

1/10/2012 Hyn, New York vear-old Duane Brown was hot and killed by New York Police Department officers

\section{$7 / 17 / 2014$}

Staten Island, New York

43 year-old $\mathrm{f}$ ric Garnet died

from being in a 15 second

cholehold by Officer Daniel

Pantaleo of the New York

Police Department.

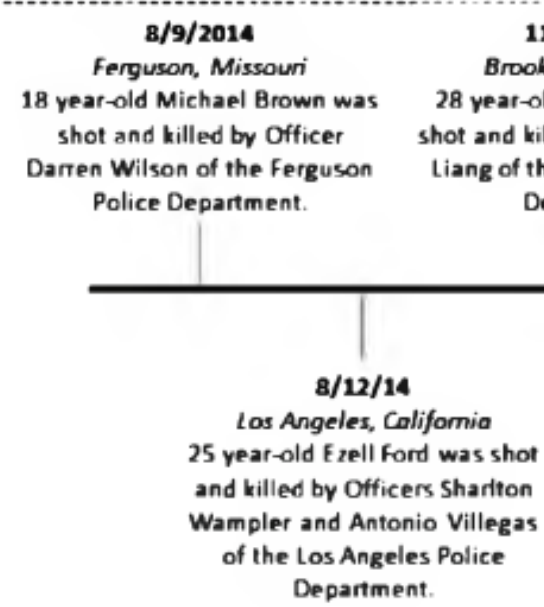

11/20/2014

\section{roldyn, New York}

28 year-old Akai Gurley was

shot and killed by Officer Peter Department.

\section{Galveston, Texas \\ 34 year-old Raymond Allen was \\ and died due to complications}

\section{$3 / 6 / 2015$}

19 year-old Tony Robinson was

shot and killed by Officer Matt

Kenny of the Madison Police

Department.

2/26/2012
Sanford, Florida
17 year-old Irayon Martin was
shot and killed by George
Zimmerman, a Sanford
neighborthood watch wolunteer.

1/16/2014

Houston, Teras

26 year-old Jordan Baler was

shot and killed by Officer

Juventino Castro of the

Houston Police Department.

3/31/2015
Vineland, New lersey
32 year-old Philip White died
due to a violent encounter
when in Vineland Police
Department custody.

$4 / 4 / 2015$

North Charleston, South Caroline

50 year-old Walter Scolt was

shot and killed by Officer

Michael Slager of the North

Charleston Police Department.

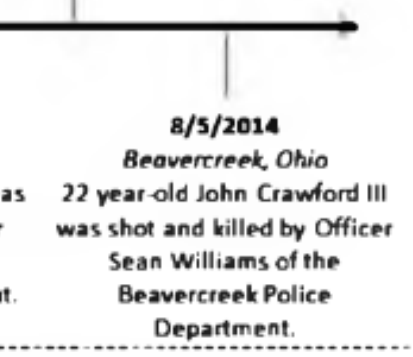

\section{Figure 1}

Figure 1. Timeline of the top 20 most publicized police killings of unarmed Black male civilians (January 1999-May 2015). After researching the police killings of unarmed Black male civilians from January 1999 to May 2015, a research assistant documented 78 incidents. The research assistant then conducted a Factiva article search, using each victim's name as the search term, to determine the top 20 incidents with the highest impact factors (i.e., the most publicized incidents according to major national news publications from 1/1/1999 to 5/8/2015). Impact factor was calculated by dividing the number of articles containing each victim's name by the number of days since the incident occurred. 


\section{References}

ABC News. (2014, November 26). Exclusive: Watch George Stephanopoulos’ full interview with police officer Darren Wilson. Retrieved from http://abcnews.go.com/GMA/video/exclusive-watch-george- stephanopoulos-fullinterview-police-officer-27186831

Allport, G. W. (1954). The nature of prejudice. Cambridge, MA: Perseus Books.

Antomo, A. L., Chang, M. L, Hakuta, K., Kenny, D. A., Levin, S., \& Milem, J. F. (2004). Effects of racial diversity on complex thinking in college students. Psychological Science, 15, 507-510. http://dx.doi.org/ 10.1111/j.0956-7976.2004.00710.x

Bardi, A., Buchanan, K. E., Goodwin, R., Slabu, L., \& Robinson, M. (2014). Value stability and change during self-chosen life transitions: Self-selection versus socialization effects. Journal of Personality and Social Psychology, 106, 131-147. http://dx.doi.org/10.1037/a0034818

Baumeister, R. F., \& Sommer, K. L. (1997). What do men want? Gender differences and two spheres of belongingness: Comment on Cross and Madson (1997). Psychological Bulletin, 122, 38-44. http://dx.doi.org/ 10.1037/0033-2909.122.1.38

Bayley, D. H. (2008). Police reform: Who done it? Policing \& Society, 18, 7-17. http://dx.doi.org/10T080/10439460701718518

Bezrukova, Y., Spell, C. S., Perry, J. L., \& Jehn, K. A. (2014). A metaanalytical integration of over 40 years of research on diversity training evaluation. Manuscript submitted for publication, http://dx.doi.org/10 .5465/AMB PP.2014.14813abstract

Binder, J., Zagefka, H., Brown, R., Funke, F., Kessler, T., Mummendey, A. . . Leyens, J. P. (2009). Does contact reduce prejudice or does prejudice reduce contact? A longitudinal 
test of the contact hypothesis among majority and minority groups in three European countries. Journal of Personality and Social Psychology, 96, 843-856. http://dx.doi ,org/10.1037/a0013470

Blair, I. V., Ma, J. E., \& Lenton, A. P. (2001). Imagining stereotypes away: The moderation of implicit stereotypes through mental imagery. Journal of Personality and Social Psychology, 81, 828-841. http://dx.doi.org/ 10.1037/0022-3514.81.5.828

Bouie, J. (2014, September 5). The new racism. Retrieved from http://www.slate.com/articles/news_and_politics/politics/2014/09/the_new_racism_mich ael_brown_and_trayvon_martin_deny_it_exists_and_smear.html

Bregman, P. (2012). Diversity training doesn’t work. Retrieved from https://www.psychologytoday.com/log/how-we-work/201203/diversity- traimng-doesntwork

Bruneau, E. G., \& Saxe, R. (2012). The power of being heard: The benefits of 'perspectivegiving' in the context of intergroup conflict. Journal of Experimental Social Psychology, 48, 855-866. http://dx.doi.org/10,1016/j.jesp.2012.02.017

Cadet, D. (2013, October 18). Jordan Davis' shooter rants about killing ‘thugs' so they ‘may take the hint and change their behavior'. The Huffington Post. Retrieved from http://www.huffingtonpost.com/2013/ 10/18/jordan-davis-shooter- rmchaeldunn_n_4123805.html

Calamur, K. (2014). Ferguson documents: Officer Darren Wilson’s testimony. NPR. Retrieved from http://www.npr.org/blogs/thetwo-way/2014/ 11/25/366519644/ferguson-docsofficer-darren-wilsons-testimony 
Chermak, S., \& Weiss, A. (2006). Community policing in the news media. Police Quarterly, 9, 135-160. http://dx.doi.org/10.1177/ 1098611105281630

Connell, N. M., Miggans, K., \& McGloin, J. M. (2008). Can a community policing initiative educe serious crime? A local evaluation. Police Quarterly, 11, 127-150. http://dx.doi.org/10.1177/1098611107306276

Correll, J., Park, B., Judd, C. M., \& Wittenbrink, B. (2002). The police officer’s dilemma: Using ethnicity to disambiguate potentially threatening individuals. Journal of Personality and Social Psychology, 83, 1314.

Correll, J., Park, B., Judd, C. M., Wittenbrink, B., Sadler, M. S., \& Keesee, T. (2007). Across the thin blue line: Police officers and racial bias in the decision to shoot. Journal of Personality and Social Psychology, 92, 1006-1023. http://dx.doi.Org/10.1037/00223514.92.6.1006

Cox, T. H., \& Blake, S. (1991). Managing cultural diversity: Implications for organizational competitiveness. The Executive, 3, 45-56.

Crank, J. P. (2014). Understanding police culture. London: Routledge.

Crockett, S. A., Jr. (2014, October 1). Listen: SC cop who shot man reaching for his wallet tells his side. Retrieved from http://www.theroot.com/articles/culture/2014/10/listen_sc_cop_who_shot_man_while_ reaching_for_his_wallet_tells_his_side.html

Devine, P. G., Forscher, P. S., Austin, A. J., \& Cox, W. T. L. (2012). Long-term reduction in implicit race bias: A prejudice habit-breaking intervention. Journal of Experimental Social Psychology, 48, 12671278. http://dx.doi.Org/10.1016/j.jesp.2012.06.003 
Dowler, K. (2005). Job satisfaction, burnout, and perception of unfair treatment: The relationship between race and police work. Police Quarterly, 8, 476-489. http://dx.doi.org/10.1177/1098611104269787

Duncan, B. L. (1976). Differential social perception and attribution of intergroup violence: Testing the lower limits of stereotyping of Blacks. Journal of Personality and Social Psychology, 34, 590-598. http://dx .doi.org/10.1037/0022-3514.34.4.590

Eberhardt, J. L., Goff, P. A., Purdie, V. J., \& Davies, P. G. (2004). Seeing Black: Race, crime, and visual processing. Journal of Personality and Social Psychology, 87, 876-893. http://dx.doi.org/10.1037/0022-3514 .87.6.876

Eligon, J. (2015, November 18). One slogan, many methods: Black lives matter enters politics. New York Times. Retrieved from http://www.nytimes, com/2015/11/19/us/one-sloganmany-methods-black-lives- matter- enters - politics.html?_r = 1

Feather, N. T. (1996). Reactions to penalties for an offense in relation to authoritarianism, values, perceived responsibility, perceived seriousness, and deservingness. Journal of Personality and Social Psychology, 71, 571-587. http://dx.doi.org/10.1037/00223514.7L3.571

Gabnelson, R., Jones, R. G., \& Sagara, E. (2014, October 10). Deadly force, in Black and White. Retrieved from http://www.propublica.org/ article/deadly-force-in-black-andwhite\#update-note

Gaither, S. E., \& Sommers, S. R. (2013). Living with an other-race roommate shapes Whites’ behavior in subsequent diverse settings. Journal of Experimental Social Psychology, 49, 272-276. http://dx.doi.org/ 10.1016/j.jesp.2012.10.020 
Gatto, L, \& Dambrun, M. (2012). Authoritarianism, social dominance, and prejudice among junior police officers: The role of the normative context. Social Psychology, 43, 61-66. http://dx.doi.org/10.1027/1864- 9335/a000081

Gatto, L, Dambrun, M., Kerbrat, C., \& De Oliveira, P. (2010). Prejudice in the police: On the processes underlying the effects of selection and group socialisation. European Journal of Social Psychology, 40, 252269. http://dx.doi.org/10.1002/ejsp.617

Gau, J. M., \& Games, D. C. (2012). Top-down management and patrol officers’ attitudes about the importance of public order maintenance: A research note. Police Quarterly, 15, 4561. http://dx.doi.org/10.1177/ 1098611111433010

Goff, P. A., Eberhardt, J. L., Williams, M. J., \& Jackson, M. C. (2008). Not yet human: Implicit knowledge, historical dehumanization, and contemporary consequences. Journal of Personality and Social Psychology, 94, 292-306. http://dx.doi.Org/10.1037/00223514.94.2.292

Goff, P. A., Jackson, M. C, Di Leone, B. A. L., Culotta, C. M., \& DiTomaso, N. A. (2014). The essence of innocence: Consequences of dehumanizing Black children. Journal of Personality and Social Psychology, 106, 526-545. http://dx.doi.org/10.1037/a0035663

Goldstein, I. L., \& Ford, J. K. (2003). Training in organizations (4th ed.) Belmont, CA: Wadsworth.

Greene, J. R. (2000). Community policing in America: Changing the nature, structure, and function of the police. Criminal Justice, 3, 299370.

Greenwald, A. G., \& Banaji, M. R. (1995). Implicit social cognition: Attitudes, self-esteem, and stereotypes. Psychological Review, 102, 4-27. 
Haley, H., \& Sidanius, J. (2005). Person-organization congruence and the maintenance of groupbased social hierarchy: A social dominance perspective. Group Processes \& Intergroup Relations, 8, 187-203.

Harrison, D. A., Price, K. H., \& Bell, M. P. (1998). Beyond relational demography: Time and the effects of surface- and deep-level diversity on work group cohesion. Academy of Management Journal, 41, 96-107.

Hawdon, J. (2008). Legitimacy, trust, social capital, and policing styles: A theoretical statement. Police Quarterly, 11, 182-201. http://dx.doi.org/ 10.1177/1098611107311852

Holland, J. L. (1985). Making vocational choices: A theory of careers. Englewood Cliffs, NJ: Prentice Hall.

Hudson, R. (2014, December 6). Being a cop showed me just how racist and violent the police are. There's only one fix. The Washington Post. Retrieved from http://www.washingtonpost.com/posteverything/wp/ 2014/12/06/i-was-a-st-louis-copmy-peers-were-racist-and-violent-and- theres-only-one-fix/

Jackson, S. E., Schuler, R. S., \& Werner, S. (2011). Managing human resources (11th ed.). Mason, OH: Cengage/Southwestern Publishers.

Jamieson, L. M., Suren, A., \& Knapp, J. (2000). A competency analysis of law enforcement training and its linkage to recreation as intervention in youth crime prevention. Journal of Criminal Justice, 28, 215-226. http://dx. doi. org/10.1016/S0047-2352(00)00037-4

Johnson, A. (2014, September 24). Capt. Ron Johnson responds to officers wearing "I am Darren Wilson” wristband. Fox2now.com. Retrieved from http://fox2now.com/2014/09/24/johnson-responds-to-question-about- officers-weanng-iam-darren-Wilson-wristbands/ 
Kang, S. K., \& Apfelbaum, E. (2012, April 12). Research-based advice on teaching children not to be racist. Retrieved from http://www.theatlantic .com/health/archive/2012/04/researchbased-advice-on-teaching- children-not-to-be-racist/255736/

Kang, S. K., \& Inzlicht, M. (2012). Stigma building blocks: How instruction and experience teach children about rejection by outgroups. Personality and Social Psychology Bulletin, 38, 357-369. http://dx.doi.org/ 10.1177/0146167211426729

Kerr, S., \& Jermier, J. M. (1978). Substitutes for leadership: Their meaning and measurement. Organizational Behavior and Human Performance, 22, 375-403.

Loftus, B. (2010). Police occupational culture: Classic themes, altered times. Policing \& Society, 20, 1-20. http://dx.doi.org/10.1080/ 10439460903281547

Lopez, G. (2014, November 26). Police thought 12-year-old Tamir Rice was 20 when they shot him. This isn’t uncommon. Retrieved from http://www.vox.eom/2014/1 1/26/7297265/tamir-rice-age-police

McConahay, J. B. (1986). Modern racism, ambivalence, and the modern racism scale. In J. F. Dovidio \& S. L. Gaertner (Eds.), Prejudice, discrimination, and racism (pp. 91-125). San Diego, CA: Academic.

Miller, S. L. (1998). Rocking the rank and file: Gender issues and community policing. Journal of Contemporary Criminal Justice, 14, 156-172. http://dx.doi.org/10.1177/1043986298014002004

Monteith, M. J. (1993). Self-regulation of prejudiced responses: Implications for progress in prejudice-reduction efforts. Journal of Personality and Social Psychology, 65, 469-485. http://dx.doi.org/10.1037/0022- 3514.65.3.469 
Najdowski, C. J., Bottoms, B. L., \& Goff, P. A. (2015). Stereotype threat and racial differences in citizens’ experiences of police encounters. Law and Human Behavior, 39, 463-477. http://dx.doi.org/10.1037/ lhb0000140

Navarrete, C. D., McDonald, M. M., Molina, L. E., \& Sidanius, J. (2010). Prejudice at the nexus of race and gender: An outgroup male target hypothesis. Journal of Personality and Social Psychology, 98, 933-945. http://dx.doi.org/10.1037/a0017931

New York Times Poll. (2014, August 21). Reactions to the shooting in Ferguson, Mo., have sharp racial divides. Retrieved from http://www .nytimes.com/interactive/2014/08/21/us/ferguson-poll.html?_r=0

Oliver, W. M. (2001). Community-oriented policing: A systemic approach to policing. Upper Saddle River, NJ: Prentice Hall.

Page-Gould, E., Mendes, W. B., \& Major, B. (2010). Intergroup contact facilitates physiological recovery following stressful intergroup interactions. Journal of Experimental Social Psychology, 46, 854-858. http:// dx.doi.org/10.1016/j.jesp.2010.04.006

Paoline, E. A. (2003). Taking stock: Toward a richer understanding of police culture. Journal of Criminal Justice, 31, 199-214. http://dx.doi. org/10.1016/S0047-2352(03)00002-3

Patton, S., \& Leonard, D. J. (2014, December 8). Viewpoint: Why Eric Garner was blamed for dying. Retrieved from http://www.bbc.com/ news/magazine-30340632

Phillip, A. (2014, December 2). Cleveland cop said he 'had no choice' but to shoot 12-year-old Tamir Rice, father says. The Washington Post. Retrieved from http:/www.washingtonpost.com/news/post-nation/wp/ 2014/12/02/cleveland-cop-saidhe-had-no-choice-but-to-shoot-12-year- old-tamir-rice-father-says/ 
Plant, E. A., Goplen, J., \& Kunstman, J. W. (2011). Selective responses to threat: The roles of race and gender in decisions to shoot. Personality and Social Psychology Bulletin, 37, 1274-1281. http://dx.doi.org/10 .1177/0146167211408617

Plant, E. A., Peruche, B. M., \& Butz, D. A. (2005). Eliminating automatic racial bias: Making race non-diagnostic for responses to criminal suspects. Journal of Experimental Social Psychology, 41, 141-156.

Podsakoff, P. M., MacKenzie, S. B., \& Bonner, W. H. (1996). Meta-analysis of the relationships between Kerr and Jermier’s substitutes for leadership and employee job attitudes, role perceptions, and performance. Journal of Applied Psychology, 81, 380-399.

Pratto, F., Sidanius, J., Stallworth, L. M., \& Malle, B. F. (1994). Social dominance orientation: A personality variable predicting social and political attitudes. Journal of Personality and Social Psychology, 67, 741-763. http://dx.doi.Org/10.1037/0022-3514.67.4.741

Riek, B. M., Mama, E. W., \& Gaertner, S. L. (2006). Intergroup threat and outgroup attitudes: A meta-analytic review. Personality and Social Psychology Review, 10, 336-353. http://dx.doi.org/10.1207/sl5327957 psprl004_4

Rubenstein, J. (1973). City police. New York: Farrar, Strauss, and Giroux.

Sagiv, L., \& Schwartz, S. H. (1995). Value priorities and readiness for out-group social contact. Journal of Personality and Social Psychology, 69, 437-448. http://dx.doi.Org/10.1037/0022-3514.69.3.437

Schuck, A. M. (2014). Female representation in law enforcement: The influence of screening, umons, incentives, community policing, CA- LEA, and size. Police Quarterly, 17, 54-78. http://dx.doi.org/10.1177/ 1098611114522467 
Schwartz, S. H. (1994). Are there universal aspects in the structure and contents of human values? Journal of Social Issues, 50, 19-45. http:// dx.doi.org/10.1111/j. 15404560.1994.tb01196.x

Sidanius, L, Liu, L, Pratto, F., \& Shaw, J. (1994). Social dominance orientation, hierarchyattenuators and hierarchy-enhancers: Social dominance theory and the criminal justice system. Journal of Applied Social Psychology, 24, 338-366. http://dx.doi.Org/10.1lll/j.1559-1816.1994 ,tb00586.x

Sidanius, J., Pratto, F., Sinclair, S., \& Van Laar, C. (1996). Mother Teresa meets Genghis Khan: The dialectics of hierarchy-enhancing and hierarchy-attenuating career choices. Social Justice Research, 9, 145- 170. http://dx.doi.org/10.1007/BF02198077

Sidanius, L, Van Laar, C., Levin, S., \& Sinclair, S. (2003). Social hierarchy maintenance and assortment into social roles: A social dominance perspective. Group Processes \& Intergroup Relations, 6, 333-352. http:// dx.doi.org/10.1177/13684302030064002

Sim, J. J., Correll, J., \& Sadler, M. S. (2013). Understanding police and expert performance: When training attenuates (vs. exacerbates) stereotypic bias in the decision to shoot. Personality and Social Psychology Bulletin, 39, 291-304. http://dx.doi.org/10.1177/0146167212473157

Sklansky, D. A., \& Marks, M. (2008). The role of the rank and file in police reform. Policing \& Society, 18, 1-6.

Skolnick, J. H. (1994). Justice without trial: Law enforcement in democratic society (3rd ed.). New York: Wiley.

Skolnick, J. H., \& Bayley, D. H. (1986). The new blue line: Police innovation in six American cities. New York: Free Press. 
Sperry, P. (2014, December 7). Eric Holder believes all cops are racists, targets 'unconscious bias’. New York Post. Retrieved from http://nypost .com/2014/12/07/eric-holder-believesall-cops-are-racists-targets- unconscious-bias/

Stephan, W. G., \& Stephan, C. W. (1996). Intergroup relations. Madison, WI: Brown \& Benchmark Publishers.

Stephan, W. G., \& Stephan, C. W. (2000). An integrated threat theory of prejudice. In S. Oskamp (Ed.), Reducing prejudice and discrimination (pp. 23-45). Mahwah, NJ: Erlbaum.

Sunshine, L, \& Tyler, T. (2003). Moral solidarity, identification with the community, and the importance of procedural justice: The police as prototypical representatives of a group’s moral values. Social Psychology Quarterly, 66, 153-165.

Swaine, J. (2014, August 17). Ferguson police officer was ‘doing his job’, say supporters. Retrieved from http://www.theguardian.com/world/2014/aug/l8/ferguson-supporterspolice-killed-teenager-protest

Tait, R. C., \& Chibnall, J. T. (2014). Racial/ethnic disparities in the assessment and treatment of pain: Psychosocial perspectives. American Psychologist, 69, 131-141. http://dx.doi.org/10.1037/a0035204

Tajfel, H., \& Turner, J. C. (1979). An integrative theory of intergroup conflict. In W. Austin \& S. Worchel (Eds.), The social psychology of intergroup relations (pp. 33-47). Montrerey, CA: Wadsworth.

Taylor, R. W., Fritsch, E. L, \& Caeti, T. J. (1998). Core challenges facing community policing: The emperor still has no clothes. ACJS Today, 17, 3-5. 
Tett, R. P., \& Burnett, D. D. (2003). A personality trait-based interactionist model of job performance. Journal of Applied Psychology, 88, 500-517. http://dx.doi.Org/10.1037/0021-9010.88.3.500

Tett, R. P., \& Guterman, H. A. (2000). Situation trait relevance, trait expression, and crosssituational consistency: Testing a principle of trait activation. Journal of Research in Personality, 34, 397-423.

Tett, R. P., Simonet, D. V., Walser, B., \& Brown, C. (2013). Trait activation theory: Applications, developments, and implications for person-workplace fit. In N. D. Christiansen \& R. P. Tett (Eds.), Handbook of personality at work (pp. 71-100). New York, NY: Routledge.

The National Center for Women \& Policing. (2002). Men, women, and police excessive force: A tale of two genders: A content analysis of civil liability cases, sustained allegations, and citizen complaints [Data file]. Retrieved from http://womenandpolicing.com/PDF/2002_Excessive_Force.pdf

Thomas, M. O., \& Burns, P. F. (2005). Repairing the divide: An investigation of community policing and citizen attitudes toward the police by race and ethnicity. Journal of Ethnicity in Criminal Justice, 3, 71-90.

Trawalter, S., Hoffman, K. M., \& Waytz, A. (2012). Racial bias in perceptions of others’ pain. PloS one, 7(11), e48546. http://dx.doi.org/10.1371/journal.pone.0048546

Turner, K. B., Giacopassi, D., \& Vandiver, M. (2006). Ignoring the past: Coverage of slavery and slave patrols in criminal justice texts. Journal of Criminal Justice Education, 17, 181-195. 
Umphress, E. E., Simmons, A. L., Boswell, W. R., \& Tnana, M. D. C. (2008). Managing discrimination in selection: The influence of directives from an authority and social dominance orientation. Journal of Applied Psychology, 93, 982-993. http://dx.doi.org/10.1037/0021-9010 .93.5.982

United States Department of Justice. (2007). Local police departments, 2007 [Data file]. Retrieved from http://www.bjs.gov/content/pub/pdf/ lpd07.pdf United States Department of Justice. (2015). Investigation of the Ferguson police department [Data file]. Retrieved from http://www .justice.gov/sites/default/files/opa/pressreleases/attachments/2015/ 03/04/ferguson_police_department_report.pdf

Van Vugt, M., De Cremer, D., \& Janssen, D. P. (2007). Gender differences in cooperation and competition: The male-warrior hypothesis. Psychological Science, 18, 19-23.

Verhovek, J. (2015, April 21). Justice department opens investigation into Baltimore death. Retrieved from http://www.cnn.com/2015/04/ 21/politics/justice-department-baltimoredeath/

Vito, G. F., Walsh, W. F., \& Kunselman, J. (2005). Community policing: The middle manager’s perspective. Police Quarterly, 8, 490-511.

Waldzus, S., Mummendey, A., Wenzel, M., \& Weber, U. (2003). Towards tolerance: Representations of superordinate categories and perceived ingroup prototypicality. Journal of Experimental Social Psychology, 39, 31-47. http://dx.doi.org/10.1016/S00221031(02)00507-3

Waytz, A., Hoffman, K. M., \& Trawalter, S. (2015). A superhumanization bias in Whites’ perceptions of Blacks. Social Psychological and Personality Science, 6, 352-359. 
Wehrman, M. M., \& De Angelis, J. (2011). Citizen willingness to participate in policecommunity partnerships: Exploring the influence of race and neighborhood context. Police Quarterly, 14, 48-69. http://dx.doi .org/10.1177/1098611110393134

Williams, T. (2015, November 18). Chicago rarely penalizes officers for complaints, data shows. New York Times. Retrieved from http://www .nytimes.com/2015/11/19/us/fewcomplaints-against-chicago-police- result-in-discipline-data-shows.html 